\title{
Broadscale Tree Clearing in Queensland
}

\section{John Rolfe}

$\mathrm{N}$ atural resource management issues remain topical in Australia as debate continues over the identification and choice of tradeoffs between various production and protection options. While much of the recent national debate has been centred on some major issues such as dry land salinity in the Murray-Darling basin and the restoration of environmental flows down the Snowy River, other issues are also topical.

An example of a less-publicised issue that occasionally reaches national prominence is broadscale tree clearing in Queensland. While broadscale tree clearing is still occurring in several Australian states, the bulk of clearing activities is in Queensland. In 1995-97, approximately 340,000 hectares per annum of both regrowth and virgin timber were cleared in the State. By comparison, the approximate area of the Australian Capital Territory is 240,000 hectares.

Clearing mostly occurs to develop land for pastoral and farming purposes. In the past, development involving land clearing has been actively encouraged by both the Commonwealth and State governments through mechanisms such as conditions on leases and taxation incentives. Over time, there has been recognition, beginning in the southern states, that the impacts of clearing on factors such as biodiversity, land degradation and salinity have not always been benign. This recognition, together with factors such as the increasing scarcity of remnant natural vegetation (RNV), has led governments across Australia to withdraw many of the incentive mechanisms and actively protect RNV areas.

Queensland has lagged behind the southern states in introducing restrictions over broadscale tree clearing. For example, while South Australia introduced clearing controls in 1983, the first substantial controls over clearing on leasehold land in Queensland were introduced in 1995, and there has been substantial debate in 1999 and 2000 over proposals to extend those controls to freehold land.

One of the reasons for this is that the pace of agricultural development in Queensland has historically lagged behind other states, meaning that there are still opportunities for development to increase production. Allied with this have been improvements in production knowledge, which make ongoing pasture development, dryland cropping and irrigation more suitable to particular regions of Queensland. Another reason is that vegetation clearing in Queensland does not always generate the same indirect costs (such as risks of increased salinity) that have become evident in southern and western areas, although many of the nonproduction costs of vegetation clearing have not been very well quantified.

Some potential costs arising from clearing relate to the long term impacts on soils and ecosystems that might ultimately affect production. Some indirect costs

John Rolfe is Research Coordinator at the Emerald Campus of the Central Queensland University. 
relate to the emissions of greenhouse gases that result from vegetation clearing. Other costs relate to factors such as biodiversity losses, which tend to be borne by the wider community that places some value on its existence. In each case a lack of knowledge and awareness may be contributing to the continued high clearing rates.

There are also a number of reasons why broadscale tree clearing in Queensland impacts on the Australian public and why the debate about tree clearing will remain on the national agenda for some time. At one level, the debate is about whether the current high clearing rates are in the interests of all Australians. Here the issues at stake are whether the production gains, which tend to be focused on short-term horizons, are substantial enough to balance out the subsequent costs. The latter might include risks of longer term production losses (such as salinity effects), other indirect effects which might occur (such as greenhouse gas emissions), and other losses (such as reductions in biodiversity).

At another level, the debate centres on issues of property rights and compensation associated with potential controls over tree clearing. Landholders in Queensland with freehold title are arguing that they should be compensated for any introduction of controls over tree clearing which would reduce their development and income potential. The Queensland Government approached the Commonwealth Government in 1999 for $\$ 100$ million for compensation measures but was rejected. As a result, the Queensland Government proposes to enact only part of the 1999 legislation introducing clearing controls over freehold land.

The debate is also likely to continue about the mechanisms by which controls are introduced over clearing. The moves to increase controls over clearing in Queensland have followed the same reliance on regulatory approaches adopted in other states. This regulatory approach from the Commonwealth and State level conflicts with two emerging trends in natural resource management. The first of these is to develop incentive-based approaches to changing behaviour where taxes, marketable permits and use charges can be levied (Portney, 2000). While market related mechanisms to improve environmental management are well established in the debate over greenhouse gas emissions, there has been little effort to link them back to potential reductions in vegetation clearing.

The second emerging trend in natural resource management is to transfer authority away from the Commonwealth and State governments to more regional and local authorities (Portney, 2000). This possibility and some of the mechanisms by which it might occur have been flagged in a recent discussion paper (Agriculture, Forestry and Fisheries - Australia, 1999). Where the spillover effects from natural resource management occur at a local or regional level, such devolution of authority makes good sense because it allows the stakeholders involved to negotiate mutually agreeable compromises. What is more unclear is how spillover effects (such as biodiversity losses) that impact on national or even international communities can be adequately registered at a regional planning and administration level.

The evidence presented in the paper suggests there is a case to further restrict clearing in some instances, but not a case to restrict clearing completely. 


\section{The Policy Debate}

Nationally, nearly 70 per cent of all vegetation has been removed or significantly modified, with as much lost in the past 50 years as in the previous 150 years (Industry Commission, 1997). Native vegetation clearing has been identified as a major contributing factor to biodiversity decline and loss (Department of the Environment, Sport and Territories (DEST), 1995; Industry Commission, 1997).

Consistent with normal commercial practice, lands with high potential productivity were cleared first in Queensland. Much of the initial clearing occurred for farming (for example, sugar cane) and dairying purposes. The introduction of mechanical clearing methods (scrubpulling) and chemical treatments, together with suitable improved pastures has meant that clearing has also been profitable in many of the pastoral zones. Over the past fifty years, clearing activities have extended further west and north in the State, across the brigalow and softwood scrub areas and into the semi-arid woodland regions. There has also been continued clearing in coastal communities, associated with further agricultural development and urban expansion (DEST, 1995).

In common with other states, vegetation on fertile soils in Queensland has been extensively cleared. For example, of the 6 million hectares where brigalow (Acacia harpophylla) was the dominant vegetation type, approximately 95 per cent had been cleared by the late 1980s (DEST, 1995). In 1997, Queensland held about 1 million hectares ( 0.5 per cent of the state) of vegetation that is classified as endangered under the Vegetation Management Act 1999 (Qld) (Boulter et al, 2000 ). While some vegetation communities were originally very limited in extent and thus classified as endangered, other communities are now classified as endangered because of extensive clearing activities.

The development of satellite mapping information by the Statewide Landcover and Tree Study (SLATS) within the Queensland Department of Natural Resources (DNR) has improved data on tree clearing rates. This project began in 1996 and its preliminary findings (DNR, 1999) can be summarised as:

- The average annual tree clearing rate between 1995 and 1997 was 340,000 hectares;

- 57 per cent of all tree clearing in Queensland is occurring within the brigalow belt biogeographic region;

- clearing rates in the Desert Uplands and Mulga biogeographic regions have declined from previous high levels;

- the Balonne shire is the Local Government Area with the highest clearing rate in Queensland, accounting for 14 per cent of the State's clearing. In the 19911995 period the Jericho shire had the highest clearing rate;

- approximately 40 per cent of clearing is occurring on leasehold land, 57 per cent on freehold land, and the remaining 3 per cent on crown land. This is a reversal of the 1991-95 situation, when clearing rates on leasehold and freehold land were 55 per cent and 42 per cent respectively; 
- the rate of tree clearing across Queensland decreased by approximately 21 per cent between the 1988-89 and 1991-5 time periods and then increased 18 per cent to the 1995-97 period;

- at least 18 per cent of 1995-97 clearing was for regrowth, and this proportion may rise as satellite data is analysed further; and

- approximately 86 per cent of vegetation change was for pasture production, and a further 9 per cent of vegetation change was for cropping.

Some cases of development of the more marginal and less fertile lands for pasture production come as graziers from the brigalow region acquire new land to the west and north of their original holdings and seek to replicate their past development successes. In other cases it occurs because graziers have become more confident in their ability to control regrowth and wish to explore new options for improving productivity. Clearing also occurs because the cost of machinery and development relative to income has trended downwards over time. The same influences that have substituted capital and machinery for labour in the rural sector over the past decades also drive the searches for increased development and make it increasingly cost effective.

\section{The policy debate at the state level}

In the past, the main focus of the debate in Queensland in relation to broad scale tree clearing has been on leasehold land, where clearing can only occur where a permit has been issued by the relevant agency of the State Government. While much of the western and northern rangelands area of the State is held as leasehold title, much of the farming and coastal zone is held in freehold title. The intermediate pastoral zone between these regions is held as a mixture of leasehold and freehold title. There have not been any controls imposed on freehold title and, prior to 1995, there has been little control over clearing on leasehold land'.

The State Government policy on leasehold land that was introduced in 1995 categorised vegetation in four groups. The Endangered and Vulnerable categories referred to vegetation types that were very limited in extent. These included communities that had been cleared to less than 5 per cent (Endangered classification) or less than 10 per cent (Vulnerable classification) of their original extent. No further clearing of these categories was to occur on leasehold land.

The Of Concern category covered vegetation types that had been previously cleared, but not to the extent of being at risk - vegetation communities that had been cleared to between 10 per cent and 30 per cent of their original extent. Some clearing was still allowed to occur in these communities. The Not of Concern category covered vegetation types where more than 30 per cent of the original

1 Leaseholders have always needed permits for clearing timber. Historically the Queensland Government has imposed clearing conditions on many leases as part of a strategy to promote development in the state. Some of these remained effective until the mid-1980s. 
extent of the vegetation remained. Vegetation in this category could continue to be cleared down to the 30 per cent level.

As well as these broad classifications, the new policy set other conditions for clearing and established a system of regional guidelines where policy could be adjusted in negotiation with regional stakeholders. Among the most important conditions were minimum retention levels on leasehold properties (set at 20 per cent), restrictions on clearing near watercourses, and bans on clearing in unproductive country types or where land degradation or salinity problems might emerge.

The new policy established some major differences between freehold and leasehold title. While freehold owners could continue to clear all vegetation types, leaseholders were restricted to the Not of Concern and Of Concern categories, and had to meet a minimum retention level of 20 per cent of each vegetation type on their properties. As well, leaseholders could only get permits to clear Not of Concern vegetation types if 30 per cent remained intact within the region. The difference provided indirect incentives for leaseholders to continue clearing (or applying for permits) before the overall limits were reached.

At the same time, the new policy could not be viewed as comprehensive in terms of protecting RNV and avoiding environmental losses in Queensland. This was partly because many vegetation communities that are concentrated on freehold land in coastal and south-east Queensland were not protected. Biodiversity was likely to continue to decline. However, many issues of resource management (such as soil degradation and erosion) were not caused directly by clearing but related more to inappropriate grazing practices (Scanlon and Turner, 1995).

At the same time there has been continued debate about the extent of native vegetation in 1788, which is the benchmark date for assessing remaining proportions. Vegetation thickening, through tree invasion into grasslands regions, and increase in tree numbers in woodland areas, is widespread in Queensland (Scanlon and Turner 1995). It has largely occurred because of increased stocking pressures and changed fire regimes that accompanied the European settlers. In some vegetation communities, clearing has both restorative elements (reversing thickening impacts) and development elements (particularly in relation to introducing non-native grasses).

The effect of the introduction of the tree clearing guidelines on leasehold land has had little impact on the rate of tree clearing in Queensland, although it has reduced clearing in a number of vegetation communities. This is in part because:

- there are substantial woodland communities listed as 'not of concern' that are perceived by landholders to have development potential;

- there are no clearing restrictions on freehold land;

- landholders can convert some lease titles to freehold title; and

- some landholders have intensified their clearing activities in anticipation of future restrictions being imposed. 
In December 1999, the Queensland government passed the Vegetation Management Bill 1999. This legislation extended controls on tree clearing to freehold land as well as leasehold land, abolished clearing in the Of Concern vegetation communities, and amalgamated the Vulnerable and Endangered classifications into a new Endangered classification. Rural lobby groups strongly criticised the legislation on a number of grounds, particularly relating to the lack of compensation for the effective change in property rights.

The Queensland Premier requested $\$ 100$ million in funding from the Commonwealth Government to assist industry adjustment. The Commonwealth refused. As a result, the Queensland Government proposes to only enact part of the Bill. Leaseholders will not be able to clear Of Concern (or Endangered) vegetation communities, while freehold owners will not be able to clear Endangered vegetation communities. A joint State-Commonwealth working group was established in early 2000 to explore ways of negotiating further changes.

\section{The Policy Debate at the Commonwealth Level}

At the Commonwealth level there has also been substantial interest in clearing activities in Queensland over recent years. The State of the Environment Advisory Council (1996) reported that vegetation clearing generally (for agriculture, urban and forestry purposes) was a major cause of biodiversity loss. The Industry Commission (1997) noted that in many areas vegetation remnants were further threatened through such problems as salinity.

The commitment of the Commonwealth Government to limiting emissions of greenhouse gases from Australia has also helped to focus some attention on tree clearing activities. In the national inventories developed, a major component of Australia's emissions have comprised of land use change emissions, largely from tree clearing activities. Total net emissions from tree clearing and regrowth activities have been estimated by the Australian Greenhouse Office to be 89.7 million tonnes of carbon dioxide $\left(\mathrm{CO}_{2}\right)$ equivalent in 1990 , and 62.9 million tonnes of $\mathrm{CO}_{2}$ equivalent in 1996 (Rolfe 1998). The Queensland Government (2000) reported that approximately 35 per cent of the State's $\mathrm{CO}_{2}$ emissions derive from land use change and forestry.

These estimates show that vegetation clearing has a significant impact on greenhouse gas emissions, and any controls or slowdown in the rate of clearing will automatically help Australia meet its emissions targets set under the Kyoto agreement. The opportunity cost of meeting reduction targets from reducing land clearing is much lower than from reducing some fossil fuel emissions (Hassall and Associates, 1999; Rolfe, 2000). While the Australian Greenhouse Office has focused on voluntary reductions and cooperative agreements to limit growth in emissions, the policy debate about greenhouse emissions will continue to have some focus on tree clearing activities.

In July 1999, the Commonwealth Government (1999) released a Draft National Framework for the Management and Monitoring of Australia's Native 
Vegetation. Its preamble notes 'that all Australian Governments have committed themselves, through the National Heritage Trust, to reverse the long-term decline in quality and extent of Australia's native vegetation cover by June 2001' (p.4). The National Framework is drafted as a partnership agreement between the Commonwealth and the States to improve vegetation monitoring and management consistent with other government strategies and policies.

These developments indicate that the Commonwealth Government, through partnership agreements with the States, is likely to have more influence over tree clearing guidelines than has previously been the case.

\section{Productivity of Pastoral Lands and Reasons for Tree Clearing}

Annual rates of productivity growth in Australian agriculture have been higher than for the economy overall over the past five decades (Industry Commission 1997). This includes the beef industry, which accounts for almost one-fifth of agricultural production nationally. Over 40 per cent of the beef cattle herd is located in Queensland, which exports about 80 per cent of the meat produced in the state. The beef industry in Queensland has grown steadily in past decades and had an estimated turnoff value of $\$ 1.2$ billion in 1996-97. The reasons for this increase can be summarised into five groups:

- pasture development, much of which is associated with tree clearing;

- improvements in the breeding of cattle;

- improvements in the provision of infrastructure (fences, waters, roads);

- improvements in management and increased turnoff rates; and

- the use of feed supplements and the growth of the feedlot industry.

Tree clearing in Queensland has tended to be associated with increased profitability and higher land values. This is to be expected. Landholders would generally only clear trees if they expect to increase production and profitability. In many cases, the landholders involved are those who are already experienced in clearing trees and establishing pastures and who are moving further west and north in search of new development opportunities. Their expectations are that they can replicate past successes in improving productivity.

While these expectations may be widespread, they are not necessarily highly defined. Graziers rarely assess pasture systematically to determine quantity and quality, which makes it difficult for them to assess the benefits of tree clearing in a precise way. Instead, the benefits of tree clearing are usually expressed in terms of improved carrying capacity (of beef cattle), which generally reflects both increased numbers and improved productivity. Carrying capacity though can be confounded with a number of other factors, including:

- climatic factors and seasonal variation;

- improvements in cattle breeding;

- changed management practices; 
- intensification (smaller paddocks and increased rotation); and

- supplementary feeding.

Increases in production in areas where tree clearing occurs appears to be slight in the context of the State production. This may be partly because tree clearing and pasture development only affects a small proportion of the State's land mass at any one period, (about 0.2 per cent per annum) and therefore possible large improvements at the property level make little impression on overall numbers. As well, such improvements may be limited in the context of other value-adding activities, such as feedlotting, within the industry.

For many graziers, the increases in productivity have been necessary to balance declining terms of trade and commodity prices. Returns in the beef industry are closely correlated with the size of the production enterprise, and for many of the smaller enterprises, returns have been negative over the past few years (Rolfe and Donaghy, 2000). The beef industry has the major debt load compared to other rural industries in Queensland (Reeve, 1999). Debt levels as a proportion of production increased sharply during the 1990s, rising from 75 per cent to 90 per cent between 1994 and 1997. On average, enterprises running less than 1,000 head of cattle appear to fall below long term viability standards.

In Queensland, approximately two-thirds of specialist beef producers have less than 1000 head of cattle, and would be expected to be financially stressed during the next drought or commodity downturn (Rolfe and Donaghy, 2000). While it is unlikely that tree clearing and development options will be enough to redress viability issues for many beef producers, there is little doubt that there is substantial pressure on producers to increase productivity.

In recent years, landholders clearing trees have been responding to perceptions of sovereign risk as well as the economic drivers. Over the past decade, there has been widespread anticipation that the Queensland Government would introduce tighter controls over tree clearing. Many landholders have brought forward their development plans and clearing rates have increased. However, because much of the most suitable agricultural land has already been cleared and more marginal land types are being developed, it is unlikely that the current high clearing rates will have a major impact on production.

The impact of clearing and development on beef production already appears low. More than six million hectares of clearing occurred in Queensland over the twenty years between 1977 and 1997 (encompassing both regrowth and virgin vegetation), but total cattle numbers have fallen over that time period and total meat production has trended only slowly upwards. The effects on profitability do not appear to be dramatic, with debt levels trending upwards for the beef industry relative to production over the 1990s. While the explanation for these overall results partly lies in the seasonal variations (the 70 s were wet, while the 90 s have been dry) and partly in long term declines in pasture production (from vegetation thickening and land degradation), they indicate that the overall gains from clearing vegetation may not be particularly high. 
However while the overall gains from clearing may be low relative to other production opportunities, they may still be worthwhile if they outweigh the financial and indirect costs that may also result. To assist the debate over the new vegetation policy in Queensland there is a need to consider the impact of tree clearing in economic terms.

\section{Assessing Costs and Benefits of Clearing Options}

The standard tool that economists use for assessing preservation and production choices is cost benefit analysis (CBA). This technique operates by assessing how people in society value the benefits and costs that flow from a particular resource use alternative. If the benefits outweigh the costs, the project is assumed to be worthwhile or desirable (economic and vice versa). In this way, economists can provide advice to decision makers in society about how the preferences of society sum-up over a particular issue.

There are a large number of factors that need to be considered in a complete CBA approach. This is because an economic analysis of a resource use option is much broader than a corresponding financial summary. There are three main categories of benefits and costs to be considered. Direct use values are those directly associated with a resource use. Indirect values are those associated with a spillover effect or other indirect consequence of a resource use. Non-use values incorporate the concerns or wishes that people might have about a resource use, even if they receive no direct or indirect benefit. While estimates of direct use benefits and costs can usually be gained from market data, indirect and non-use costs and benefits have to be estimated in different ways.

Pastoralists generally respond to direct use benefits when they clear trees in the expectation that the returns from increased carrying capacity outweighs the cost of clearing, pasture development and subsequent maintenance. As well, pastoralists might also factor in their personal preferences for items such as biodiversity conservation, the aesthetics of tree cover, and the risks of longer term impacts such as salinity. However, there are a range of costs and benefits that may not be considered by pastoralists that include community (non-use) values for biodiversity, indirect effects on greenhouse gas emissions and off-farm costs of land degradation. A summary of the costs and benefits of tree clearing is presented in Table 1.

In the absence of government intervention, tree clearing occurs where landholders balance up the benefits and costs at the property level and perceive that higher returns are available from pursuing clearing options. While some landholders may only consider the benefits and costs of development in the short term, others may be inclined to factor in a variety of medium to longer term considerations that they consider important. This means that among landholders there will be some diversity in the balance struck between production and preservation alternatives.

At a simplified level, the key issues to consider are the main direct use benefits (represented by the commercial returns from tree clearing), the indirect effects on land quality and greenhouse gas emissions, the attitudes of the wider 
community to biodiversity loss and the welfare of rural communities. For policy makers, the issue can be framed in terms of whether the commercial gains available from tree clearing continue to outweigh the net losses associated with indirect and non-use impacts.

Table 1. Social Costs and Benefits of Tree Clearing

\begin{tabular}{|l|l|l|}
\hline \multicolumn{1}{|c|}{ Impacts } & \multicolumn{1}{|c|}{ Benefits } & \multicolumn{1}{c|}{ Costs } \\
\hline \multicolumn{1}{|c|}{ Property level } & \multicolumn{1}{|c|}{$\begin{array}{l}\text { Direct, medium term } \\
\text { pasture OR Increase in land } \\
\text { future income }\end{array}$} & $\begin{array}{l}\text { Income from improved } \\
\text { pasture, controlling regrowth and } \\
\text { additional infrastructure }\end{array}$ \\
\hline Indirect, longer term & $\begin{array}{l}\text { Possible reduction in grazing } \\
\text { pressure on rest of property }\end{array}$ & $\begin{array}{l}\text { Reduced benefit of tree cover } \\
\text { (shade, shelter, nutrient } \\
\text { recycling) } \\
\text { Pastoralists own value for risk of } \\
\text { salinity, erosion }\end{array}$ \\
\hline $\begin{array}{l}\text { Improved access for mustering } \\
\text { quality }\end{array}$ & $\begin{array}{l}\text { Pastoralists own value for } \\
\text { biodiversity loss }\end{array}$ \\
\hline $\begin{array}{l}\text { Costernal impacts } \\
\text { gases }\end{array}$ & $\begin{array}{l}\text { Possible reduction in land } \\
\text { degradation on some } \\
\text { properties }\end{array}$ & $\begin{array}{l}\text { Possible increased risk of } \\
\text { salinity, erosion on other } \\
\text { properties and above landholder } \\
\text { expectations }\end{array}$ \\
\hline $\begin{array}{l}\text { Social value of } \\
\text { biodiversity }\end{array}$ & $\begin{array}{l}\text { Reduced economic welfare from } \\
\text { higher greenhouse gas emissions }\end{array}$ \\
\hline $\begin{array}{l}\text { Indirect effects of } \\
\text { production }\end{array}$ & $\begin{array}{l}\text { Social value of positive effects } \\
\text { on rural communities from } \\
\text { more profitable agricultural } \\
\text { sector }\end{array}$ & $\begin{array}{l}\text { Reduced economic welfare from } \\
\text { biodiversity loss }\end{array}$ \\
\hline
\end{tabular}

Source: Adapted from Rolfe, Bennett and Blamey (2000).

\section{Commercial gains}

In Queensland, the commercial production benefits available from tree clearing vary widely according to the vegetation type and production opportunities. After the initial clearing, there is a spike in pasture production, followed by declines caused by falling soil fertility and competition from regrowth. ABARE (1995) quotes Burrows (1990) as indicating that the removal of trees can increase initial pasture production by 2 to 7 times. Treatment of regrowth can be used to maintain pasture production above the pre-clearing levels. 
Burrows (1999) reports that the net present value of clearing in the Popular Box woodlands of central Queensland ranges between $\$ 40-\$ 64 / \mathrm{ha}$, according to different timber treatments and allowing for a 20 per cent retention rate. In the Desert Uplands region further to the west, Resource Consulting Services (1999) report from two case studies that the net present value of developing ironbark and wattle country is $\$ 12.34 / \mathrm{ha}$, and $\$ 28.31 /$ ha for ironbark and box country.

In each of these cases, overhead expenses, unpaid family labour and a return on capital invested in land and equipment have not been included in the estimation of net returns per hectare. At the property level, where landholders may be considering additional clearing, this exclusion may be commonplace. However, when these additional costs are included to develop an overall picture of net returns per hectare, the returns are likely to be much lower. This is because these additional costs are a substantial proportion of inputs.

\section{Indirect effects}

The experience of environmental problems in other parts of Australia suggest that there are a number of factors which need to be considered in relation to tree clearing activities on more marginal land types. In particular, there has been a substantial debate in recent years about the fragility of rangeland ecosystems in Australia and the impact of pastoral activities (Boulter et al, 2000). Some of the debate focuses on what are sustainable pastoral activities (for example, Wilson, 1990) while other commentators focus on the importance of pastoralists and other resource managers understanding and working with natural ecological processes (Foran et al, 1989).

It is possible that there may be some unintended ecological consequences of tree clearing that will ultimately reduce the production base of the State in the longer term. There are limited issues with soil erosion in some areas, although many problems are associated with management and stocking pressure rather than the initial clearing. Landsberg et al (1998) documents how some landholders have begun to understand the fragility of land types in relation to stocking rates and change management practices accordingly. In a few areas where erosion is already a degradation problem, clearing trees and replacing the vegetation with grass can actually arrest erosion problems.

Impacts on soil structure and fertility declines can be issues in some regions. It is well established that pasture growth surges in the years immediately following tree clearing, buming and pasture establishment. Paddocks typically run more cattle, grasses are more responsive to rainfall events, and cattle fatten better. The reasons for this include the removal of competition for water and nutrients, increased herbage production, improved water infiltration, a 'fertiliser spike' from burning and rotting vegetation and the introduction of grasses more palatable to domestic stock.

After the initial surge in production, the carrying capacity of pastures tends to diminish for reasons such as emerging regrowth, reduced water infiltration, soil compaction, reduced nutrient availability and so on (Scanlon and Turner, 1995; 
CSIRO, 1998). While it is likely that many improved pastures remain more productive than the original vegetation form for many years, it is unclear whether declines in nutrients and elements such as phosphorous mean that such developments are not sustainable in the longer term. It is also unclear whether high levels of clearing have long term impacts on soil fertility (for example, through net reductions in organic carbon) or change the ecology at a paddock level (for example, increasing insect pressure by predator removal) in ways that ultimately reduce agricultural production.

Indirect effects of clearing on dryland salinity is an issue in some regions of Queensland, although the State has low levels of salinity compared with southern and western parts of Australia (Gretton and Salma, 1996). One of the notable facets of salinity is that its effects have often been poorly anticipated in Australia by landholders, scientists and regulators. This is also the case in Queensland, where there is increasing evidence that dryland salinity problems associated with tree clearing may be more substantial than had previously been considered (Williams et al, 1997; CSIRO, 1999). There is increasing evidence that some risks of salinity may be associated with tree clearing in parts of the Murray-Darling basin in Queensland (CSIRO 1999). In some specific case studies, the risks of salinity will need to be considered carefully in any analysis of the potential costs.

Another indirect impact of tree clearing is the subsequent release of greenhouse gases, principally carbon in the form of carbon dioxide ${ }^{2}$. This occurs when timber is burnt or rots after clearing. It also occurs when the below ground biomass (tree roots) rots or when there is an impact on organic carbon levels in soils. It is difficult to quantify the overall release of greenhouse gases from clearing activities for a number of reasons.

The amount of biomass varies across sites according to factors such as vegetation type, soil type and climatic influences. The measurement of carbon levels is imprecise because of the limited amount of data available and the early stages of scientific development of the appropriate modelling relationships. These difficulties are more pronounced for below-ground biomass and soil carbon levels compared to above ground biomass. As well, carbon releases from different sources occur at varying rates and both release and sequestration patterns are confounded with seasonal fluxes. The estimation of the actual areas of each vegetation type is also imprecise, making it difficult to extrapolate site data to aggregate amounts.

Given these uncertainties, some broad estimates of the amount of carbon that might be released from tree clearing in some areas can be made. Burrows et al (1997) report that for the grazed woodlands of northern Queensland, the average basal area of all woody plants was $9.62 \mathrm{~m}^{2} / \mathrm{ha}( \pm 0.95)$. They also report that the mean above ground biomass of Eucalyptus trees (the dominant genus type in these woodlands regions) is $4,235 \mathrm{kgs}$ of matter per $\mathrm{m}^{2}$ of basal area or approximately

2 The material in this and the following four paragraphs is based on Rolfe et al (2000). 
40.74 tonnes $/ \mathrm{ha}^{3}$. At approximately 46 per cent carbon, the total mass of above ground carbon is 18.7 tonnes/ha.

To this estimate for above-ground carbon must be added the below-ground stock (approximately 30 per cent of above-ground stocks to a one metre depth) and soil carbon levels. Burrows (personal comm) suggests that net below-ground and soil carbon stocks remain relatively unchanged after tree clearing because below-ground biomass decays tend to be balanced by pasture and soil carbon increases. If this is the case, then the net carbon loss from tree clearing in the northern Eucalypt woodlands can be estimated at the above-ground biomass of 18.7 tonnes per hectare. While this is a very approximate estimate, it will give some idea of the external losses associated with this factor of tree clearing.

Trade in carbon offsets is an emerging market with many initial trades occurring in the region of around \$10US/tonne of carbon. Rolfe (1998) summarises a number of international forestry carbon offset programs as costing between $\$ 1.50$ and $\$ 12.50$ Australian per tonne of carbon ${ }^{4}$. Within that range, the indirect losses associated with greenhouse gas emissions from tree clearing in woodlands regions appear to lie between $\$ 28$ and $\$ 233$ per hectare. Lockwood and Walpole (1999) selected $\$ 10$ tonne of carbon dioxide as an appropriate benchmark, which converts to approximately $\$ 2.70 /$ tonne of carbon. At this price, the value of the loss in greenhouse gas emissions from tree clearing in the northern eucalypt woodlands is approximately $\$ 50.50 / \mathrm{ha}$.

More work is needed to quantify carbon losses from tree clearing at the property level and estimate appropriate price levels.

\section{Non-use values}

One important consideration in assessing tree clearing is the existence of community values for biodiversity preservation. These may be held, even if people are not directly affected by the use of the natural resources. State, national and even international populations may hold concerns about biodiversity loss that should be taken into account in any formal appraisal of overall costs and benefits. As well as these concerns, there may also be community values for the welfare of regional communities and the impacts that any further loss of agricultural production might have on the livelihood of people in these regions.

There is limited research available to determine the exact consequences of tree clearing on biodiversity in Queensland. Worldwide, there is very good evidence to link tree clearing with biodiversity loss. Scanlon and Turner (1995) reported that some further biodiversity loss was still likely to occur from tree clearing in Queensland even after the more restrictive guidelines had been brought in. Some impacts on biodiversity occur because of the fragmentation of habitat

3 Burrows (personal comment) reports that estimates of above ground biomass for eucalypts in northern Queensland are being revised upwards, and may be approximately 6 tonnes per $\mathrm{m}^{2}$ of basal area.

${ }_{4}$ Prices for carbon offsets are likely to fall further as new opportunities for offsets are found and the markets continue to develop. 
that results from clearing. Fairfax and Fensham (1999) note that in many central Queensland vegetation communities it is the introduction and spread of buffel grass following clearing that has the most significant impact on biodiversity. The dominance of buffel grass reduces the diversity of native plants.

The difficulty for decision makers wishing to assess the public good aspects of resource allocation choices (these non-use and some indirect use values) is that they can not be inferred from direct observation of behaviour. This is because there is little or no incentive to provide these services through market mechanisms. One of the challenges is to price such effects. Valuation techniques have been developed to estimate non-use values, but have rarely been used in Australia to estimate preservation values for native remnant vegetation.

One of these techniques, termed Choice Modelling (CM), has been used to estimate the value of remnant vegetation and potential changes to broad scale tree clearing regulations in the Desert Uplands, a biogeographic region of Queensland that is approximately the size of Tasmania (Blamey et al, 1999). In that project, the main issues were condensed (for logistical and modelling purposes) to six possible attributes, namely:

- Payment by society for changes (Levy on income taxes);

- Income lost to the Desert Uplands region (\$ million);

- Jobs lost to the Desert Uplands region;

- Number of endangered species lost to the Desert Uplands region;

- Reduction in population size of the non-threatened species; and

- Loss in area of unique ecosystems.

The survey process involved people in Brisbane being asked to make choices between different scenarios made up of varying levels of these attributes. The results of the experiment indicate the preservation values that households in Brisbane have for protecting both environmental factors and the livelihood of people living in rural communities.

The results can be demonstrated with preservation values for a number of different options to increase vegetation protection, as shown in Table 2. For example, Option D illustrates that there is substantial willingness to pay for moderate increases in protection to remnant native vegetation in the region that have some offsetting social costs (losses in regional income and jobs). Option $\mathrm{E}$ shows that it is only when the offsetting social costs become much larger (for example, 10 per cent of jobs are lost) that the household willingness to pay falls to zero. These estimates can be multiplied by the number of households in Brisbane (approximately 800,000) to indicate the total preservation values for this subset of the state population.

The options presented in Table 2 indicate that values are weighted towards at least some increase in protection levels above the current standard, and towards the protection of endangered species. Rolfe et al (2000) compared these non-use values with production opportunities in the Desert Uplands region to conclude that for slight to modest increases in vegetation protection, (up to more than 30 per 
cent of the region) the values of biodiversity protection would outweigh both substantial social impacts and potential production losses. Once protection levels were increased above 50 per cent of the region, the estimated benefits of biodiversity protection were lower than the estimated production losses and social costs. However, when the value of possible greenhouse gas emissions are also factored in, it appears that many tree clearing activities in the region may be uneconomic from the overall viewpoint of society.

Table 2: Brisbane Households: Willingness to Pay for Preservation Options

\begin{tabular}{|l|c|c|c|c|c|}
\hline & \multicolumn{5}{|c|}{ Change from current trends } \\
\hline \multicolumn{1}{|c|}{ Attribute } & OPTION A & OPTION B & OPTION C & OPTION D & OPTION E \\
\hline $\begin{array}{l}\text { Jobs lost in the } \\
\text { region }\end{array}$ & 10 & 30 & 50 & 50 & 180 \\
\hline $\begin{array}{l}\text { Regional income } \\
\text { Lost }\end{array}$ & $\$ 5$ million & $\$ 10$ million & $\$ 5$ million & $\$ 10$ million & $\$ 10$ million \\
\hline $\begin{array}{l}\text { Additional species } \\
\text { preserved in area }\end{array}$ & 2 & 10 & 2 & 2 & 2 \\
\hline $\begin{array}{l}\text { Additional \% of } \\
\text { non-threatened } \\
\text { species preserved }\end{array}$ & $30 \%$ & $45 \%$ & $10 \%$ & $10 \%$ & $10 \%$ \\
\hline $\begin{array}{l}\text { Additional area of } \\
\text { unique ecosystems } \\
\text { preserved }\end{array}$ & $10 \%$ & $20 \%$ & $30 \%$ & $30 \%$ & $30 \%$ \\
\hline Willing to pay & $\$ 76$ & $\$ 88$ & $\$ 80$ & $\$ 74.50$ & $\$ 0$ \\
\hline
\end{tabular}

Source: Rolfe et al (2000)

It is not clear how transferable these results are to other regions of the state where tree clearing activities are present. The Desert Uplands region is an area of lower production potential than many other regions, so the opportunity costs of preserving vegetation will tend to be lower. However, it is a region that has not yet been extensively cleared and, because of its largely leasehold tenure, effectively has substantial preservation measures already in place. In comparison, many of the regions that have been heavily cleared in the past are dominated by freehold tenure, meaning that there is still little control over future clearing activities. It appears likely that across all regions, some clearing activities that are currently permissible are not economic when all preferences of society are taken into account.

\section{Conclusion}

The debate over vegetation clearing in Queensland will continue for some time into the future. While some clearing activities are uneconomic when the indirect costs and biodiversity impacts are factored in, it does not automatically follow that all clearing should be stopped. In some cases, vegetation clearing may still be worthwhile when all factors are considered. Clearing may also be valid to restore 
landscapes where vegetation has intruded into grasslands or thickened from scattered woodlands over the past 200 years. In many cases, treatment of regrowth vegetation will continue in areas where the original clearing occurred in a much earlier time period.

These complexities illustrate that part of the debate will continue about where the limits to clearing should be set. Identifying where the tradeoff between development and preservation should occur will always be difficult, particularly across such a diverse state as Queensland. While the use of regional guidelines and planning processes may help, it is unclear how easy it will be to consider all the costs and benefits of clearing at that level.

While clearing rates remain high, the pressures for preservation and the values for remaining vegetation remnants will continue to rise. This means that there is likely to be increased pressure for increased regulation and restriction of clearing activities. In the current situation, landholders face some risk of generating negative external images about their environmental credentials, which may impact on both political and consumer support. As well, a lack of clearing regulations essentially favours landholders who clear first. This means that there may also be a lot of advantages for landholders in developing a framework for reducing clearing rates. It is likely that the debate will move away from the need to introduce regulations towards a focus on the timing and structure of those regulations.

A third area of debate will be likely to focus on effective ways of reducing clearing rates. While governments have traditionally favoured regulatory mechanisms for this purpose, there is growing interest in the advantages of other approaches. For example, incentives could be structured in the form of stewardship payments that focused on biodiversity protection or the careful maintenance of significant remnants. Rights to carbon offsets could be granted to particular vegetation types as a way of signaling to landholders that there is more value in retaining vegetation than in developing it. Providing better information to landholders about risks of salinity or erosion may be enough to reduce clearing rates in some areas.

A simplistic focus on regulatory mechanisms to achieve reductions in clearing rates may be very costly in terms of administration, the difficulties of allowing flexible outcomes and the problems of providing the right incentives for care of native vegetation remnants. It is more likely that packages of measures will be more effective, in both political and economic terms, in encouraging vegetation retention. Finding the right structure and balance between regulatory approaches and other alternatives will be the subject of continued debate in coming times.

\section{References}

Agriculture, Forestry and Fisheries - Australia (1999), Managing Natural Resources in Rural Australia for a Sustainable Future, Canberra (Discussion Paper). 
Australian Bureau of Agricultural and Resource Economics (ABARE) (1995) Analysis of the Economic Impacts of the Draft State Guidelines on Tree Clearing in Queensland, Report to the Ministerial Consultative Committee and the Working Group on Tree Clearing, Brisbane.

Blamey, R., J. Rolfe, J. Bennett, and M. Morrison (1999), 'Valuing Remnant Vegetation Using Choice Modelling: An application to the Desert Uplands of Queensland', Paper presented to the 43rd Annual Conference of the Australian Agricultural and Resource Economics Society, Christchurch.

Boulter, S., B. Wilson, J. Westrup, E. Anderson, E. Turner and J. Scanlon (eds) (2000), Native Vegetation Management in Queensland: Background, Science and Values, Department of Natural Resources, Brisbane.

Burrows, W. (1990), 'Prospects for increased production in the north east Australian beef industry through pasture development and management', Agricultural Science 3:19-24.

Burrows, W. (1999), 'Tree clearing - rehabilitation or development on grazing land?', Paper presented to the Sixth International Rangelands Conference, Townsville, 17-18 July.

Burrows, W., E. Anderson, P. Back, and M. Hoffman (1997), 'Regrowth and Woody Plant Thickening/Invasion Impacts on the Land Use Change and Forestry Inventory', Paper presented to the International Panel on Climate Change Experts Workshop, Rockhampton, 15-18 September.

Commonwealth Government (1999), National Framework for the Management and Monitoring of Australia's Native Vegetation, available at http://www.environment.gov.au.

CSIRO (1998), Diversity and Sustainability in Grassy Eucalypt Systems, Land and Water Resources Research and Development Corporation, Canberra (Occasional Paper No 4/98).

CSIRO (1999), The Salinity Audit of the Murray Darling Basin, Canberra.

Department of the Environment, Sport and Territories (1995), Native Vegetation Clearance, Habitat Loss and Biodiversity Decline, Paper No. 6, Biodiversity Series, Canberra.

DNR (1999), Statewide Landcover and Trees Study, Interim Report, Brisbane, available at http://www.dnr.qld.gov.au/slats.

Fairfax, R. and R. Fensham (1999), 'The Effect of Land Clearance on Floristic Diversity in Central Queensland, Australia', mimeo, Qld Herbarium, Brisbane.

Foran, B., M. Friedel, N. Macleod, D. Stafford-Smith, and A. Wilson (1989), Policy Proposals for the Future of Australia's Rangelands, CSIRO, Canberra.

Gretton, P. and U. Selma (1996) Land Degradation and the Australian Agricultural Industry, Industry Commission Staff Information Paper, AGPS, Canberra.

Hassall and Associates (1999), 'Greenhouse, Carbon Trading and Land Management', Land and Water Resources Research and Development Corporation, Canberra (Occasional Paper No. 23/99).

Industry Commission, (1997), A Full Repairing Lease: Inquiry into Sustainable Land Management, Draft Report, AGPS, Canberra.

Landsberg, R., A. Ash, R. Shepherd and G. McKeon (1998), 'Learning from History to Survive in the Future: Management Evolution on Trafalgar Station, North-East Queensland', The Rangeland Joumal 20(1):104-117.

Lockwood, M. and S. Walpole (1999), Benefit Cost Analysis of Remnant Native Vegetation Conservation, Report No. 130, Johnstone Centre, Albury. 
Portney, P. (2000), 'Environmental Problems and Policy, Joumal of Economic Perspectives 14(1):199-206.

Queensland Government (2000), Queensland Energy Policy: A Cleaner Energy Strategy, Brisbane.

Reeve, J. (1999), 'The Effect of Farm Debt on Extension Technique', pp. 206-214 in P. Long, P. Donaghy and J. Grimes (eds), 2020 Vision - Extension in the New Millennium, Proceedings of the Central Queensland Extension Forum, DPI, Rockhampton.

Resource Consulting Services (1999), Summary of Case Study Results for Development in the Desert Uplands, Report prepared for the Desert Uplands Buildup and Development Strategy Committee, Barcaldine.

Rolfe, J. (1998), 'Carbon Offsets and Land Use Change', Paper presented to the Land Development Option Forum, October 27, Barcaldine.

Rolfe, J. (2000), 'Carbon Offsets and Tree Clearing in Australia: The Potential for a Domestic Trading Scheme', Paper presented to the Energy in a Sustainable Environment Conference, Central Queensland University, June 23-5, Rockhampton.

Rolfe, J., J. Bennett and R. Blamey (2000), An Economic Evaluation of Broadscale Tree Clearing in the Desert Uplands Region of Queensland, University College, The University of New South Wales, Canberra (Choice Modelling Research Report No. 12).

Rolfe, J. and P. Donaghy (2000), 'Welfare Benefits: The Changing Face of the Queensland Beef Industry", Paper presented at the 44th annual conference of the Australian Agricultural and Resource Economics Society, 25 January, Sydney.

Scanlon, J. and E. Turner (eds) (1995), The Production, Economic and Environmental Impacts of Tree Clearing in Queensland, Report to the Working Group of the Ministerial Consultative Committee on Tree Clearing, Department of Lands, Brisbane.

State of the Environment Advisory Council (1996), Australia: State of the Environment 1996, CSIRO Publishing, Melbourne.

Williams, J., E. Bui, E. Gardner, M. Littleboy and M. Probert (1997), 'Tree Clearing and Dryland Salinity Hazard in the Upper Burdekin Catchment of North Queensland', Australian Joumal of Soil Research 335:785-801.

Wilson, A. (1990), 'The Effect of Grazing on Australian Ecosystems', Proceedings of the Ecological Society of Australia 16:185-194.

Earlier versions of this work have benefited from the helpful comments of Peter Donaghy, Jeff Bennett, Bill Burrows and Blair Bartholomew, as well as the editors and an anonymous referee. The usual caveat applies. 